\title{
THOMAS SAY'S FREE-LIVING MITES REDISCOVERED ${ }^{1}$
}

\author{
By Arthur Paul Jacot \\ U. S. Forest Service, New Haven, Conn.
}

Thomas Say, the earliest American to record mites from the United States, described a possible six species of free living mites from eastern Georgia and Florida. They were obtained from the late fall to the early spring. Say mentions as places visited by him (9) Fernandina (on Amelia Island), St. Mary's, Darien, Cumberland Island, and Savannah which he reached (homeward bound) on April 11th 1818.

Although I was able to collect at these localities during April, I found the soil and litter so dry that there were very few mites about. I was informed by the Weather Bureau that it had not rained for two months, a very unusual condition. The Islands east of Savannah were much burned over and I obtained no mites from them. The only type of collecting done was to look under the bark of trees and under stones-these being the only niches mentioned by Say. I found no stones, but a few tiles at one place. They yielded nothing.

Say described two species of Trombidium. I found three species of mites resembling Trombidiids, securing nineteen specimens of a Smaris, fourteen specimens of a Trombicula, and four specimens of a Microtrombidium. All these were taken from under the bark of prone trunks. A careful study of Say's T. sericeum reveals a body shape typical of Smaris. The only character that does not fit Smaris is the short, silken hair.

Now turning to Say's T. scabrum. If one divides a Trom-

${ }^{1}$ Aided by a grant of the Elizabeth Thompson Science Fund. 
bicula at the constriction, calling the portion behind the constriction the abdomen and the part anterior to it the thorax, then Say's description: "ovate body, broadest and very obtusely rounded before, with thorax obtriangular," accords with that genus, at least far more so than with any other Trombidioid. Moreover the surface of this Trombicula is "unequal, with numerous indentations." The discrepancies are, "minutely scabrous." "With hardly perceptible hairs" may be true enough but these two statements seem contradictory. The description of the hairs of T. sericeum fits T. scabrum and vice versa! Eyes white is difficult to explain unless Say took for eyes what I take to be eyes in this otherwise eyeless genus. If he saw these eyes he must have seen the hairs correctly in both species (genera) but must have gotten his two descriptions mixed.

At any rate he secured two Trombidioid looking mites from trees in April. I secured two species from the same localities and niche in April. My most common species is unquestionably the same as his most common (Smaris). On the whole his descriptions fit my two commonest Trombidioids. Therefore, until someone can duplicate our collecting and get quite different results, I will have to accept these two species as described below.

\section{Trombiculoides gen. nov.}

Resembling Trombiculus but with area sensiligera much more highly developed, triangular, with one of the angles directed posteriad, the others laterad (figures 1 and 2); immediately posteriad of the lateral angles are rounded bosses which appear to be eyes. This area sensiligera is situated in a hollow or recess formed by the highly developed lateral lobes of the thorax, which extend far anteriad and tower above the sensiligerous area. The anterior edge of the abdomen (s.s.) also encroaches on the area and also towers high above it, thus very much secluding this sensitized area.

Type: Trombiculoides scaber comb. nov.

The presence of eyes (for the structures in question have every appearance of eyes) in this area and in this group, makes this species quite distinct from all other Trombidiids. 
Trombiculoides scaber (Say) 1821, p. 69

(Figures 1 and 2)

Diagnostic characters: Superficially resembling a Trombicula, but with the characters of this genus. Pseudostigmatic organs long, fine, simple; palps with simple bristles on dorsal face, and unilaterally ciliate bristles on sides, especially the lateral sides, the three spines of palptibia closely approximated (figure 2); palptarsus nearly three times as long as broad.

Description: Size fairly large, ovigerous females $1.36 \mathrm{~mm}$. long; tarsi I oval, $0.246 \mathrm{~mm}$. long and $0.09 \mathrm{~mm}$. high; color rose red; abdomen broadly oval, constriction strong, lateral lobes of "thorax" large, bulby (figure 1) ; prothorax low, extending considerably beyond lobes of metathorax, anterior edge notched (figure 1), covered with bristles (only the anterior three of one side are figured) ; all bristles of abdomen and thorax typical of Trombicula, with about sixteen cilia along the bristle but irregularly disposed, so that the bristle is ciliate all about; base of sensiligerous area with a few bristles (insertions only indicated in figure 2), anterior edge with a median crest or ridge, another such ridge at lateral angles; pseudostigmata widely separated, close to lateral angles, sides of area ribbed; the "eyes" much larger than pseudostigmata; legs rather short (figure 1) ; legs I as long as body; tarsi I not much larger than tibiae I, but longer, with small hooks; tarsi II to IV with distal end tapering conspicuously.

Material obtained: Nine specimens from under the bark of a large prone oak; outskirts south of Savannah, slides 36S3, 36S5. Five specimens from under bark of prone pine trees, outskirts north of Darien ; slide 36S6-1.

In the same niche with these mites were many mollusks, some pseudoscorpions, and the blue-tailed skink [Eumeces fasciatus (L.)]. Would this lizard be the host of the larvae of this Trombiculoid?

Smaris sericea (Say) 1821, p. 70

(Figures 3 to 6)

Diagnostic characters: Body elongate, ovate, with rather 
short "rostrum" (figure 3) ; eyes one on each side, colorless; pseudostigmatic organs present at both ends of crista, setaceous; bristles of dorsum short blunt, forming a boatshaped crest backed by an oval shield; thumb of palptibia with five bristles (figure 5).

Description: Size of ovigerous females: length $1.36 \mathrm{~mm}$., breadth $0.68 \mathrm{~mm}$.; color of body vermillion, legs paler; shape of body (figure 3) ovate, rather elongate, rounded behind, anterior end broad, with rounded "shoulders," cephaloprothorax much narrower, capable of considerable lateral retraction so that in most alcoholic specimens the posterior half is much broader than anterior half (figure 3), in nature the upper part of the cephaloprothorax is slender so that the lower half flares out on each side (figure 4) ; crista metopica extends as a slender almost undifferentiated area from broadest area of abdomen nearly to tip of "rostrum" where it divides to straddle this region (figure 4); both pairs of pseudostigmatic organs setaceous, gradually tapering but lined with four rows of short, crowded, black cilia; anterior pair one-and-a-half times length of body bristles, posterior pair two to three times length of body bristles; eyes on transverse plane passing through center or slightly posteriad of center of crista, colorless, diameter equal to length of body bristles.

Bristles of dorsum of body formed of an ovate, membranous plate or shield strengthened by fine radiating ribs the ends of which barely project beyond edge of shield. From the longitudinal center of this shield there springs the keel of a canoe-shaped crest, the edges or gunwales of which are studded by the protruding ribs of the boat (figures 6). Bristles of venter more slender, crest more slender, both crest and shield barbs lengthened into long spines which are fewer in number. These spines give the bristle the appearance of a bearded wheat head.

Legs I a little longer than body (figure 3), other legs shorter; legs I with distal trochanters as long as femora; legs II to IV with distal trochanters shorter than femora and somewhat fused to femora to form a semianchylosed, nonfunctional joint. Leg bristles as body bristles but more elongate, crest more slender, parallel sided, points of barbs much produced as minute spines. Tarsal bristles with five 
longitudinal rows of such spinules springing from outer face of bristles, giving them the appearance of well combed hedge-hogs.

Bristles of palps simple to slightly burred at base, fairly long (figure 5).

Material obtained: One specimen from under bark of a large prone oak, outskirts south of Savannah; slide 36S3. One specimen from under bark of felled pine trees, outskirts north of Darien, slide 36S8-1. These mites and Trombiculoides scaber occurred to the extent of one in about every twenty linear feet. Thirteen specimens from under bark of old log, St. Simon Island; slides 36S8-2 and 36S8-3. Four specimens from under bark of old log, Amelia Island, between Fernandina and the sea beach; slide 36S10.

The nearest European species is S. ampulligera (2, fasc. $39: 10$ ) but the bristles are entirely different. I am, at present, unaware of synonyms.

I have this species from the woodlands of western North Carolina. Smaris longilinealis (3, p. 61, pl. 9, fig. 14; 4, p. 88, pl. 4, figs. 22, 23) from Marion and Urbana, Illinois, judging from the armature of the palps, seems to be this species. I have not seen the types. In the original description Ewing reports a single pair of eyes; in his later description he records a double pair. The size given in this second description corresponds to the Georgia specimens.

Smaris sp. (Figure 7)

Similar to the European species in that there are foliose bristles on palps. Bristles of abdomen broad cuneiform, distal end truncate to emarginate, the crest barely standing out from the shield, usually bearing three longitudinal rows of barbs (figure 7, right upper) or two divaricating rows (figure 7, left upper). Figure 7, right lower, is distofrontal aspect, while the left lower are distal aspects.

From under bark at base of hickory trees, Coscob headland, Conn.

Erythraeus mamillatus Say 1821, p. 70

The description calls to mind Labidostoma; the marginal impressed line being the juncture of notogaster and ventral 
plate which might give this effect. The description fits no Erythraeus.

I found no Labidostoma.

Gamasus spinipes Say 1821, p. 71

This may be a Holostaspis (s.l.) or a Cyrtolaelaps (s.1.). I know of no free living species which fits the description which is rather detailed as to leg characters. As all of Say's other Parasitids were parasitic, this one also may have been. He gives neither locality, habitat nor host.

\section{Oribata glabrata Say 1821, p. 73}

I have already referred to this species (5, p. 260). None were found. It is the commonest Oribotritia of the south.

\section{Bdella oblonga Say 1821, p. 74}

(Figure 8)

Say describes the distal segment of the palp (the palptarsus) as "attenuated towards the base and truncated at tip." This places the species in Bdella sensu strictu. The size, "rather more than one-twentieth of an inch" that is one-sixteenth, makes it the common species of Bdella of that region. This species differs from the European Bdella longicornis in that: of the two lateral bristles of palptarsus (figure 8), the distal is much shorter and finer than the proximal (the reverse is true in specimens from northern Europe); the pseudostigmatic organs are quite persistent while they seem quite deciduous in the European species.

Bdella decipiens ( 7 and 8 ) seems to be closely related, but palptarsus has only six bristles.

Bdella oblonga seems to be common throughout the eastern United States. I find no geographical races. Bdella cardinalis $(1$, p. 219$)$ is therefore a synonym. Bdella lata (4, p. 69, pl. 2, fig. 9) is also a synonym and Ewing's figure 9 a very good toto figure of Bdella oblonga except that one bristle of palptarsus has been omitted. The toto figure of Bdella cardinalis (4, pl. 1, fig. 6) is inaccurate and should be discarded. Figure 5 is good as far as it goes, but figure 7 lacks two bristles on palptarsus and has two extra bristles on the genual. 
Florida specimens of Bdella oblonga are without dark pigment, but dark material sometimes occurring inside the body gives the abdomen a mottled appearance. One specimen from Florida (lot 90) has "black" pigmented eyes. One specimen from among several from Mt. Logan, Chillicothe, Ohio (slide 32M108a1) and one from Bent Creek, Buncombe Co., N. Car., each have the two lateral bristles of palptarsus subequal. In identifying this species one must bear in mind that the bristles of palptarsus have a varied appearance depending on orientation of the segment. In what I would call the optimum orientation four of the bristles are on one face of the segment (though near the edge) while a fifth (seventh) is on the opposite face (figure 8).

Material examined: Four specimens from well decayed fallen trunks, and moss thereon, top of slope, Calhoun Pines, Cornwall, Conn.; taken August 26th 1932, slides 3255a1 and -a2. Three specimens from leaf mould, Shawnee State Forest, Otway, Ohio; taken September 23rd 1926 by August E. Miller, slide 34M22a2. One specimen from ant's nest under bark of dead stumps, Eselgroth's woods, (four miles east of) Chillicothe, Ohio; taken April 26th 1925 by Miller, slide 32M57a2. Of eighty-six square-foot blue-grass sod samples taken weekly by A. E. Miller at Mt. Logan, Chillicothe, the following were obtained: one specimen May 5th 1924, slide 32M94a; two on August 10th 1924, slide $32 \mathrm{M} 108 \mathrm{a} 1$; one on October 6 th 1924 , slide $32 \mathrm{M} 81 \mathrm{a} 2$; three on March 9th 1925, slide 32M139a; two on March 16, slide 32M140a; one on March 30th, 32M137a2; one on April 13, $32 \mathrm{M} 63 \mathrm{a}$; one on April 20, 32M9a; one on April 27, 32M7a; one on May 4, 32M21a1; one in October 19, 32M35a; one on December 7, 32M58a (thus, in grassland, commonest in the early spring). The following were taken by Vera G. Smith: one specimen from ground, forest edge (flood plain), lower striplands, Vermillion Co., Ill.; taken June 29th 1926, slide 2390 ; from University woods, Urbana: three from leaves, March 29th 1926, slide 1085; one from leaves, August 2nd, lot 5815; one from leaves, August 16th, lot 3548; one from herbs, August 21st, lot 4370. Two specimens from bark chips, Dodson's woods, Urbana; taken August 21st 1926 by Miller, slide 32M1a. One under loose bark of untoped, fallen 
white oak, same woods ; taken June 6th 1927 by Miller, slide 32M125a1. One under loose bark, Brownfield's woods, Urbana; taken June 9th 1926 by Miller, slide 32M13. Four from exposed logs and stumps in open woods near Muncie, Ill.; taken June 22nd 1927 by Miller, slide 32M147. One from under loose bark of fallen log, open woods meadow, Sidney, Ill.; taken June 21st 1926 by Miller, slide 32M8a. Four from moist, loose bark of fallen log in woods along Salt Fork Creek, south of Oakwood, Ill.; taken May 11th 1926 by Miller, slide 32M124a. One specimen from beneath bark of fallen tree, a few miles south of Savannah, Ga.; taken April 1936, slide 36S5. Two specimens from litter, horticultural grounds Gainesville, Fla.; taken February 13th 1928 by Edgar F. Grossman, lot 13. One (with pigmented eyes) from same place, taken February 29th, lot 30. One from near insectary, horticultural grounds, Gainesville; no date, taken by H. E. Bratley, lot 90 . One from hickory litter, Pinkoson Springs; taken March 4th 1928 by Grossman, lot 33. One from long leaf pine litter, south shore of Newman's Lake, Gainesville; taken March 25th 1928 by Grossman, lot 55. Two from Tamola littoralis litter, shore bay, north beach, St. Augustine, Fla.; taken March 7th 1928 by Grossman, lot 34. Two from same locality; taken April 1st 1928 by Grossman, lot 63 . One from live oak litter, Crescent City, Fla.; taken May 1st 1928 by Grossman, lot 82. One from litter, Bradenton, Fla.; taken May 2nd 1928 by George F. Weber, lot 87. Two from live oak and pine litter, Perry, Fla.; taken February 2nd 1928 by Grossman, lot 10. One from pine litter, between Perry and Mayo, Fla.; taken April 28th 1928 by Grossman, lot 78. Nine from deciduous litter, Villa Tasso, Choctawhatchee Bay, Fla.; taken May 18th 1928 by R. W. Blacklock, lot 101.

The following species are undescribed:

Bdella trisetosa $s p$. nov.

(Figure 9)

Small, total length of largest specimen $0.82 \mathrm{~mm}$.; with dark pigment generally distributed but abdomen paler; rostrum with only two pairs of bristles (in addition to the distal); mandibles with attenuate chelae; lateral bristles 
(of cephaloprothorax) subequal to interpseudostigmatic, nearly as long as dorsal bristles of abdomen; eyes with pigmented ground; posterior eyes at widest part of cephaloprothorax, anterior eyes twice their diameter from posterior eyes; pseudostigmata on transverse plane slightly anterior to posterior eyes; the usual nine bristles of dorsum of abdomen fairly long but the three anterior mesal pairs not as long as their interspaces; lateral face of palptarsus with three subequally long bristles (figure 9), the posterior of the three is most ventrally inserted; distal end of palptarsus tapering markedly, hyaline collar of lateral bristle quite long and prominent (figure 9).

Cotypes: Two specimens from leaf litter about base of trees in an abandoned orange grove, five miles beyond Micanope, Fla.; taken February 26th 1928 by Edgar F. Grossman, slide G28Bd1 and -Bd2.

\section{Spinibdella wilsoni $s p$. nov.}

(Figures 10 and 11)

Fairly large, total length of gravid female $1.3 \mathrm{~mm}$.; with dark pigment restricted to prothorax and cephalon in immatures, slightly more extensive in adults; rostrum with two pairs of bristles (in addition to the distal) ; mandibles with attenuate chelae, the only bristle inserted near base of chelae (figure 11) ; lateral bristles of cephaloprothorax much shorter than interpseudostigmatic which are about half length of dorsal bristles of abdomen; eyes with pigment, distant their own diameter; anterior bristles of dorsum of abdomen nearly as long as interspaces; dorsal face of palptarsus with one long (longer than the segment) straight bristle; lateral edge with two bristles (figure 10): the distal one subequal to length of segment, the proximal one much shorter, mesal face with two bristles, both rather short, distal end with both major bristle cups highly developed (figure 10).

Material examined: One specimen from leaf litter, sunny, rather dry, live oak and pine, Perry, Fla.; taken February 2nd 1928 by E. F. Grossman, slide G10Bd1. One specimen from leaf litter, high, dry, under hickory tree, Pinkoson Springs, Gainesville, Fla.; taken March 4th 1928 
by Grossman, slide G33Bd1. Six specimens from leaf litter of Tamola littoralis, shore bay, seven miles from south point of North Beach, St. Augustine, Fla.; taken March 7th 1928 by Grossman, slides G34Bd1 to -Bd4 (cotypes). One specimen from leaf litter and grass, old laboratory, Bradenton, Fla.; taken March 14th 1928 by George F. Weber, slide G44Bd1 (more pigmented). One specimen from Cortez, Fla.; taken March 15th 1928 by Weber, slide G45Bd1.

Material collected under the Elizabeth Thompson Science Fund is to be deposited at the Museum of Comparative Zoölogy. Material from the Grossman collection is being returned to Dr. J. W. Wilson of the Agricultural Experiment Station of Florida.

\section{LITERATURE CITED}

1. Banks, Nathan, 1894 (June), Some New Acarina, Trans. Am. Ent. Soc., vol. 21, pp. 209-222.

2. Berlese, Antonio, 1882-1900, Acari, Myriapoda et Scorpiones hucusque in Italia reperta. Padova, 101 fasc. (10 vols.).

3. Ewing, H. E., 1909 (Aug. 16), New North American Acarina, Trans. Acad. Sci. St. Louis, vol. 18, pp. 53-77, pls. 8-11.

4. Ewing, H. E., 1910 (Mar. 1), A Systematic and Biological Study of the Acarina of Illinois, The University Studies, vol. 3 as part of Univ. Ill. Bull., vol. 7, no. 14, 120 pp., 8 pls., 6 txt. figs.

5. Jacot, A. P., 1933 (April), Phthiracarid Mites of Florida, Jour. Elisha Mitchell Sci. Soc., vol. 48, pp. 232-267, pls. 19-22, 2 txt. figs.

6. Say, Thomas, 1821, An Account of the Arachnides of the United States, Jour. Acad. Nat. Sci. Phil., vol. 2, pp. 59-82.

7. Thorell, T., 1871, Om Arachnider fr. Spetsbergen och BeerenEiland, Oefv. Kongl. Vet.-Akad. Förhandl., vol. 28, no. 6, p. 699.

8. Trägardh, Ivar, 1902, Zur Kenntnis der Litoralen Arten der Gattung Bdella Latr., Bihang till K. Sven. Vet.-Akada. Handl., vol. 27, Afd. 4, no. 9, 24 pp., 2 pls.

9. Weiss, H. B., and Ziegler, 1931, Thomas Say, Early American Naturalist.

\section{DESCRIPTION OF PLATE XIV}

Trombiculoides scaber (Say) .

Fig. 1. Dorsal aspect, appendages of one side and bristles omitted; ratio $\mathrm{x} 24$.

Fig. 2. Dorsal aspect of cephaloprothorax and a palp, most of the bristles omitted; ratio x 200 .

\section{Smaris sericea (Say)}

Fig. 3. Dorsal aspect, three legs and bristles omitted; ratio x24. 
Psyche, 1938

Vol. 45, Plate XIV.

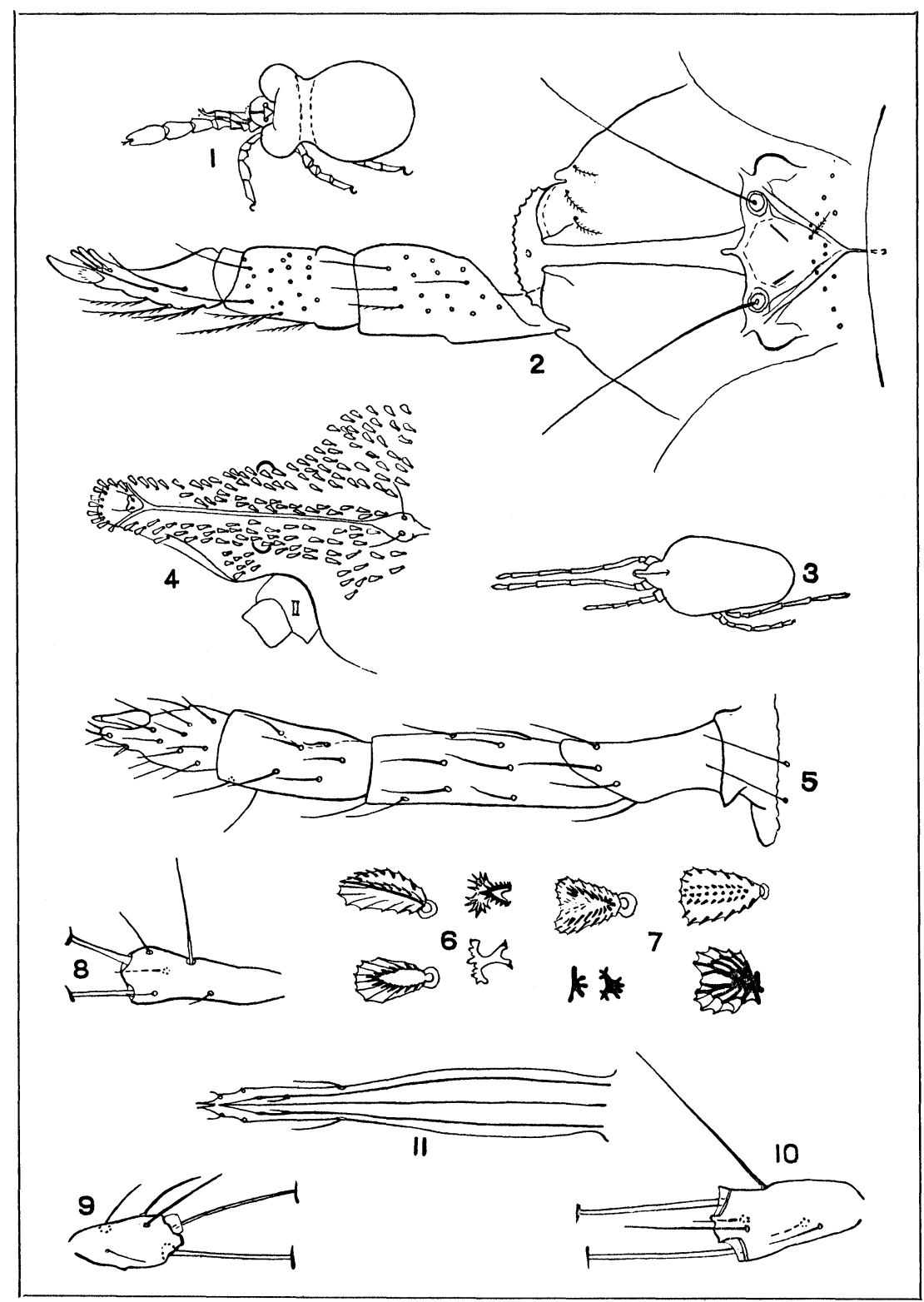

Jacot - Free-living Mites 
Fig. 4. Dorsal aspect of cephaloprothorax; ratio $x 75$.

Fig. 5. Ventral aspect of a palp, extruded; ratio x330.

Fig. 6. Various aspects of bristles of dorsum of abdomen; ratio $x 440$. The bristle to the left of the numeral and below it is as seen full face, that above is as seen somewhat from the side, the others are end views.

\section{Smaris sp.}

Fig. 7. Various aspects of bristles of dorsum of abdomen; ratio $\mathrm{x} 440$. Figures to the left of the numeral and below are end views, the others are full face, except the lower right which is somewhat from the end.

\section{Bdella oblonga Say}

Fig. 8. Palptarsus; ratio x200.

Bdella trisetosa sp. nov.

Fig. 9. Left palptarsus, dorsal aspect (lower edge of figure is mesal face); ratio $\mathrm{x} 440$.

Spinibdella wilsoni sp. nov.

Fig. 10. Mandibles lying over rostrum; ratio x200.

Fig. 11. Palptarsus, lateral aspect (lower edge of figure is ventral edge); ratio x330. 

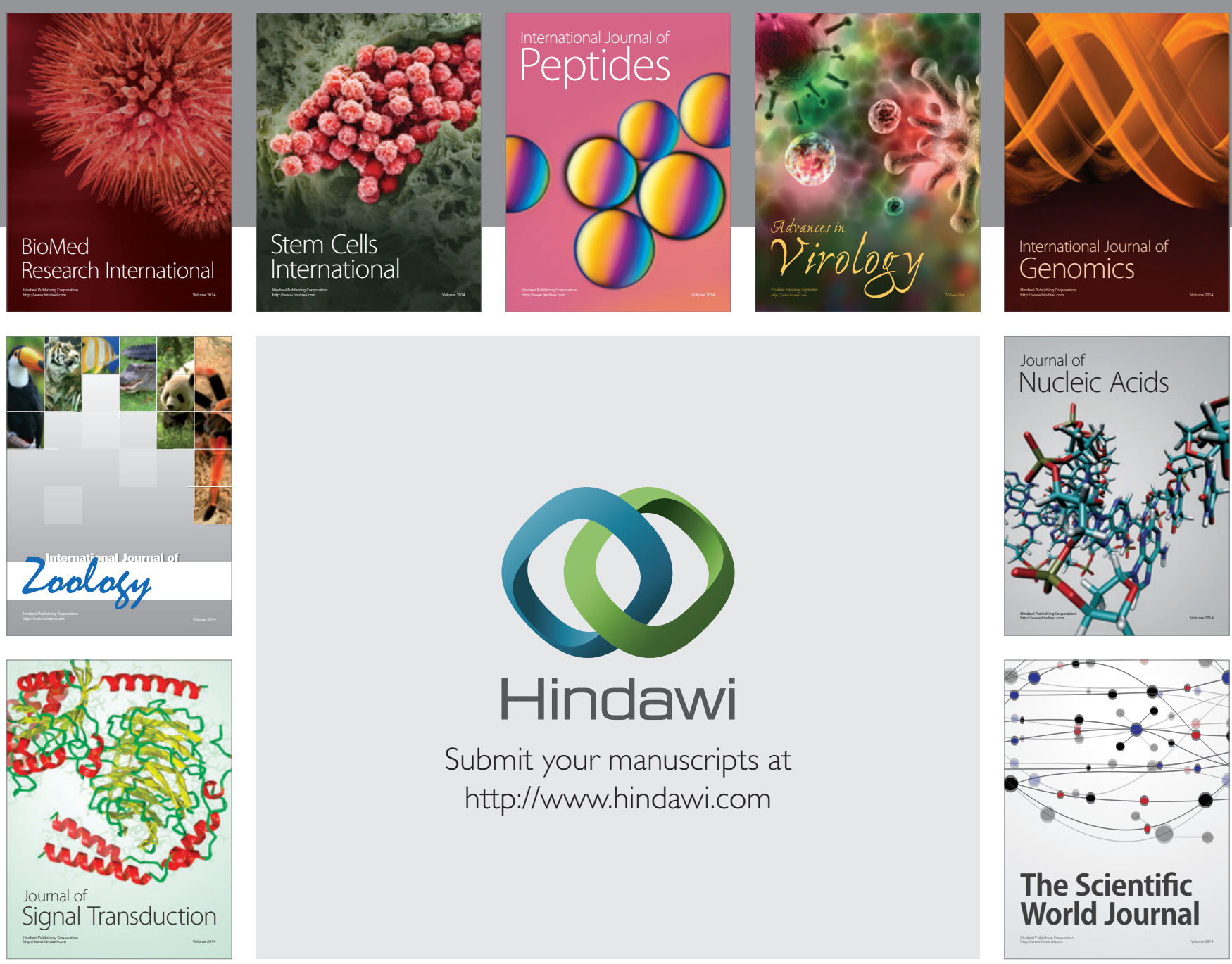

Submit your manuscripts at

http://www.hindawi.com
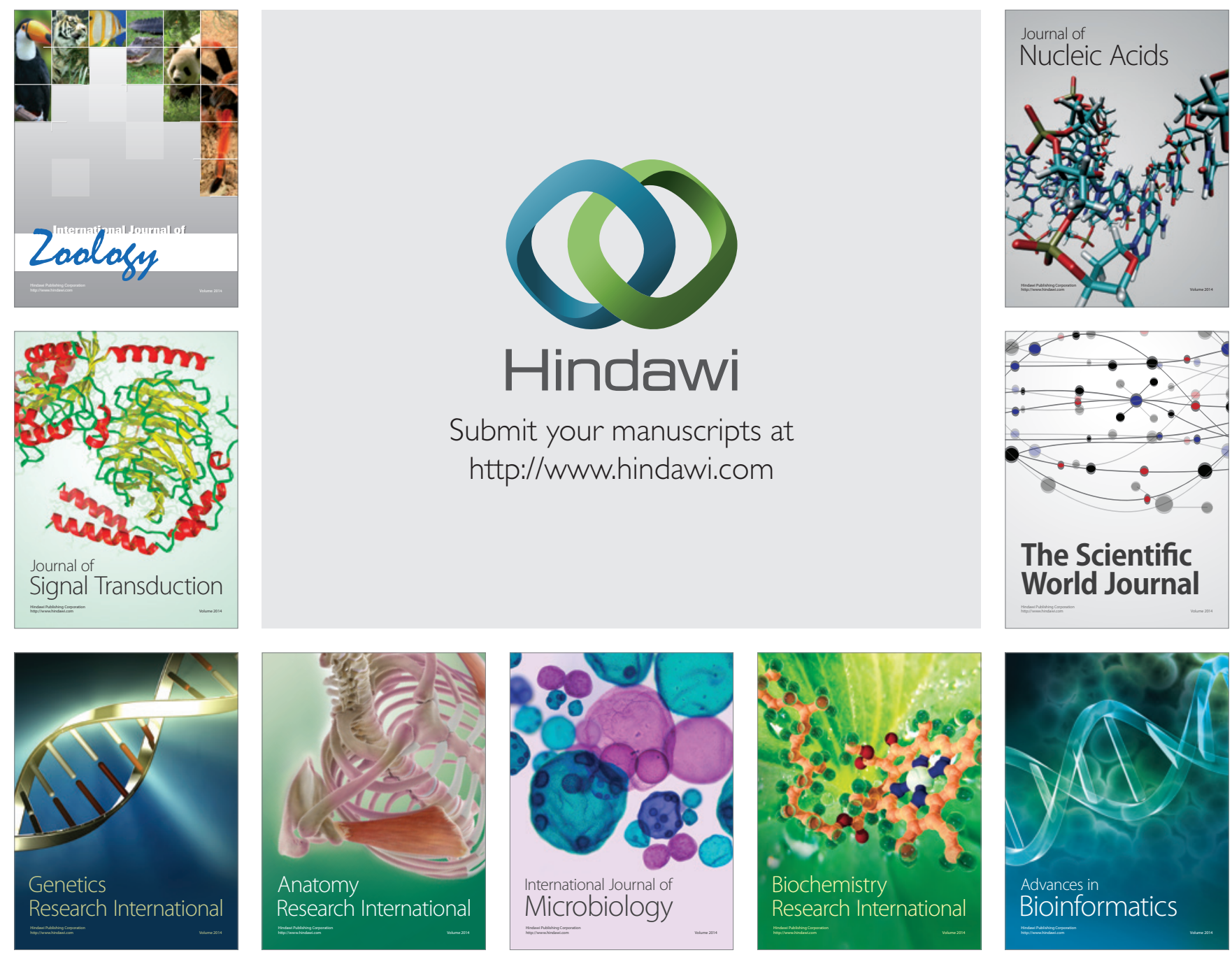

The Scientific World Journal
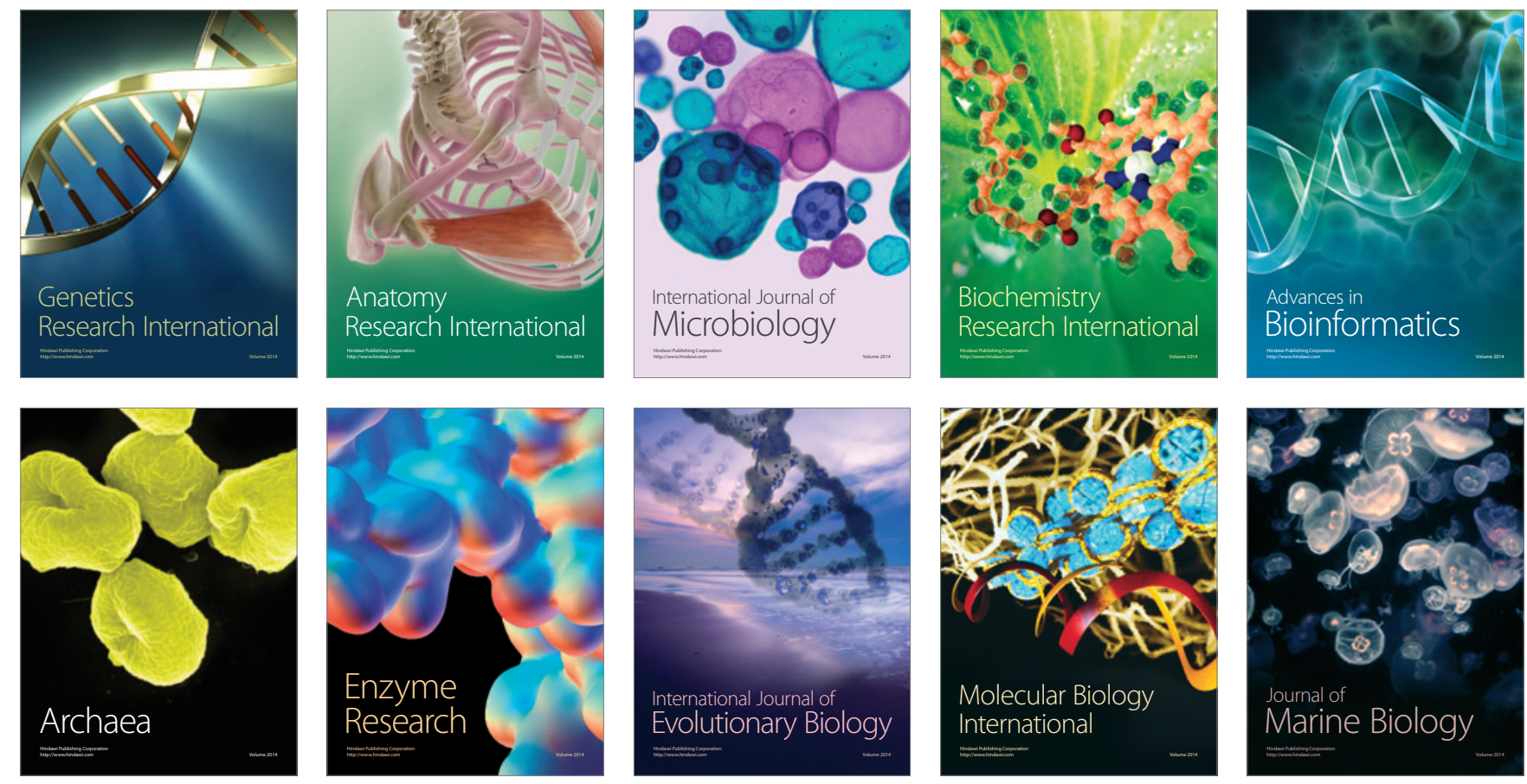